ACTA THERIOLOGICA

Vol. 24, 27: 379-389, 1979

\title{
Food Consumption, Preferences and Storage in the Mole
}

\author{
Oluwadare FUNMILAYO ${ }^{1}$
}

Funmilayo O., 1979: Food consumption, preferences and storage in the mole. Acta theriol., 24, 27: 379-389 [With 4 Tables].

Moles (Talpa europaea Linna e us, 1758) were trapped in pastures in south-east Scotland from March to August, 1969 and in January, 1970. The weight of the stomach contents of each mole was determined. Stomach contents were identified and earthworms and insect larvae were weighed separately. The food preferences of the mole were determined by comparing the proportion of stomachs and soil samples containing each category of invertebrates. Mole fortresses were examined for earthworm stores and the species distribution of earthworms in mole fortresses and in the local soils was compared. There were no significant $(P=0.05)$ monthly, sexual, age or local differences in stomach content weight. Moles subsisted almost exclusively on earthworms and insect larvae and the qualitative composition of diet was basically similar in the sexes, in adults and juveniles and in the two localities examined. The proportion by weight of earthworms in the diet was however significantly higher $(P=0.05)$ in January than in any other month while insect larvae were relatively more important in the diet from May to July. The proportion of stomachs containing different categories of invertebrates corresponded with the distribution of invetebrates in the soil indicating that the mole has no major preferences of particular food items. Both captive and wild moles stored earthworms.

[Dept. Agric. Zool., School of Agric., Edinburgh EH9 3JG, Scotland].

\section{INTRODUCTION}

The mole subsists mainly on earthworms (Lumbricidae) and insect larvae (White, 1914; A dams, 1920; Larkin, 1948; Godfrey \& Crowcroft, 1960; Skoczeń, 1966). Godfrey \& Crowcroft (1960) stated that the proportion of earthworms and insect larvae in the diet is fairly stable throughout the year but La r k in (1948) and S k oc z e n (1966) observed the consumption of more insects during the warmer months. These previous results were based only on the frequencies of occurrence of food items in stomachs. In the present study, in addition to the identification of stomach contents the weight of earthworms and insect larvae in the diet was measured and compared between months, sexes, adults and juveniles and localities.

G o d f r e y \& C r o w c r of t (1960) and S k o c z e ń (1966) have shown that males have heavier full stomachs (empty stomach and stomach con-

1 Present address: Dept. Agric. Biol. Univ. Ibadan, Ibadan, Nigeria. 
tents) than females on the average and in certain months and that food consumption increases in females during lactation. The comparisons in the present report are based on the weight of the stomach contents, rather than on that of the full stomachs, because of the large variations within and between males and females in the weight of the empty stomach (F unmila yo, 1970).

Moles are known to store earthworms which M a c Douga 1 (1942) suggested were caught during hard frost. E $\dot{\mathrm{v}}$ a n $\mathrm{s}$ (1948) speculated that the earthworms in stores were caught while crawling in the mole's tunnels, but Sk oc z en (1961) emphasised that earthworm stores were associated with winter nests and were collected during digging in mild spells in autumn and winter. Different reasons have been adduced for the preponderance of large earthworms in stores ( $\mathrm{E} v$ a n S, 1948; S k oc z e ń, 1961) which is partly why $R$ a w (1966) has called for further closer investigations on the storage of earthworms by moles. Observations on the storage of earthworms by both wild and captive moles were made in the present study.

Folitarek (1932), Godfrey \& Crowcroft (1960) and Mella n b y $(1966,1967,1968,1973)$ have suggested that the mole obtains its food principally by gathering the invertebrates that fall into existing tunnels and also by making fresh excavations both for immediate food supply (Godfrey, 1955) and to expand the size of existing tunnels to increase their productivity. The mole's methods of obtaining its food indicate that a knowledge of its food preferences could be obtained by comparing the occurrencies of invertebrates in its stomach contents with those in the local soils as was done by $\mathrm{Kru}$ is htal (1934). The food preferences of moles in Boghall glen were examined during the current study.

\section{MATERIALS AND METHODS}

Moles were killed with wDuffus* traps in three pastures in south-east Scotland. One hundred and thirty-five moles were obtained in Boghall glen between March and August 1969 while 46 others were killed in January, 1970 in Leip field and Bilston field, separated by $2.5 \mathrm{~km}$.

The date and site of capture and sex, of each mole were recorded. Each stomach was removed and preserved in formalin for 24 hours to harden the contents after which the stomach was rinsed in water, dried on filter paper and weighed. The stomach was emptied and the empty stomach cleaned, dried on filter paper and weighed. The weight of the stomach content was taken as the difference between the weight of the full stomach and that of the empty stomach.

The stomach content was divided into categories: earthworms, insect larvae, adult insects, earthworm cocoons, slugs and centipedes. All earthworms were weighed together after which small ones (Allolobophora caliginosa, A. chlorotice, 
Eisenia rosea and Dendrobaena $\mathrm{sp}$.) which were swallowed whole and large ones (Lumbricus terrestris and Octolasium cyaneum) which occurred in stomachs in recognizable pieces were identified. All insect larvae were weighed together and then identified to families. Monthly, sexual and age variations in stomach content weight and the qualitative composition of the diet were determined for moles captured in Boghall glen, while local variations in these parameters were determined for moles captured in Leip and Bilston fields.

The food preferences of the mole was determined by comparing the frequencies of occurrence of invertebrates in 165 soil cores taken in Boghall glen in May, 1969, with those in the stomachs of moles killed in the same habitat during the same period. The soil cores were taken with a cylindrical $10 \mathrm{~cm}$. diameter steel soil corer to a depth of $20 \mathrm{~cm}$., the level of the deepest mole tunnels in most parts of the study habitat.

The period of the appearance of new fortresses was recorded. Fortresses were examined for earthworm stores in March and October, 1968 and in February, March and May, 1969. Earthworms found in stores were identified (cf. Ge r a r d, 1964) and the proportional occurrence of each species in mole stores and in the local soil populations was compared. The distribution and population density of earthworms in the local soils were determined by extracting earthworms from $1 \mathrm{~m}^{2}$ soil samples with dilute formalin ( $\mathrm{R} \mathrm{a} \mathrm{w}, 1959$; F u m il a y o, 1970). Observations on the storage of earthworms and other relevant feeding habits were made during investigations on the daily food consumption of captive moles ( $\mathrm{F}$ u n mila y o, 1977).

\section{RESULTS}

\subsection{Diet}

Earthworms and insect larvae occurred in a high proportion of stomachs in all months confirming their importance as food sources to the mole. There were considerable variations between months in the proportion of stomachs containing individual families of insect larvae, earthworm cocoons, slugs, centipedes and adult insects (Table 1). The frequency of occurrence in stomachs may not give a true picture of the importance of a food item in the diet. Thus, insect larvae occurred in all stomachs in March and April but contributed less weight to the die than earthworms which occurred only in $89 \%$ and $86 \%$ of stomachs in March and April respectively. The proportion by weight of earthworms in the diet showed no significant monthly variations except in January when it was significantly higher $(P=0.05)$ than in any other month. Insect larvae appear relatively more important in the diet from May to July, the main insect larvae at this period being Tipulid larvae. Noctuid larvae were large but usually few in each stomach. Elaterid, Dolichopodid and Carabid larvae were found in many stomachs but they were small and occurred only at one to five per stomach, therefore their small sizes and few numbers per stomach made them unimportant as food items. 
Monthly, sexual, age and local variations in the

\begin{tabular}{|c|c|c|c|c|c|c|c|}
\hline \multirow[b]{2}{*}{$\begin{array}{l}\text { 营 } \\
\text { : } \\
\text { క. }\end{array}$} & \multirow[b]{2}{*}{ 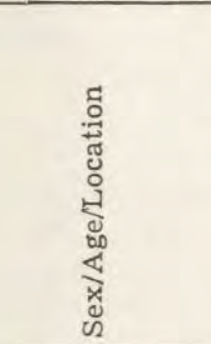 } & \multirow[b]{2}{*}{ 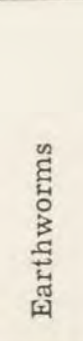 } & \multirow[b]{2}{*}{ 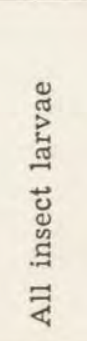 } & \multicolumn{4}{|c|}{$\frac{0 \mathrm{Nn} \text {. of } \mathrm{stomachs}}{\text { Families }}$} \\
\hline & & & & 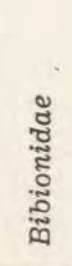 & 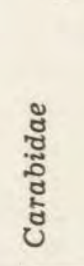 & 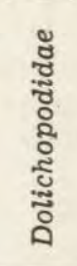 & 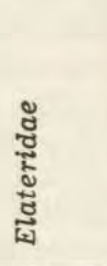 \\
\hline March 1969 & All moles & 88.9 & 100 & 44.4 & 11.1 & 11.1 & 33.3 \\
\hline April 1969 & All moles & 86.4 & 100 & 59.2 & 50.0 & 27.3 & 50.0 \\
\hline \multirow[t]{2}{*}{ May 1969} & All moles & 100 & 100 & 14.4 & 50.4 & 60.8 & 54.0 \\
\hline & All moles & 85.0 & 97.5 & 5.0 & 50.0 & 7.5 & 20.0 \\
\hline \multirow[t]{2}{*}{ June 1969} & Adults & 84.2 & 100 & 10.5 & 68.4 & 10.5 & 26.3 \\
\hline & Juveniles & 85.7 & 95.2 & - & 33.3 & 4.8 & 14.3 \\
\hline July 1969 & All moles & 90.0 & 93.6 & - & 39.6 & 21.6 & 46.8 \\
\hline August 1969 & All moles & 100 & 100 & - & - & - & - \\
\hline March to & All moles & 90.0 & 97.7 & 17.5 & 43.5 & 25.9 & 38.2 \\
\hline \multirow{4}{*}{ August 1969} & Males & 88.9 & 97.4 & 22.1 & 41.6 & 28.6 & 42.9 \\
\hline & Females & 90.9 & 98.1 & 11.1 & 46.3 & 22.2 & 31.5 \\
\hline & Leip field & 100 & 84.8 & - & 12.1 & - & 57.6 \\
\hline & Bilston field & 100 & 61.5 & 15.4 & - & 7.7 & 15.4 \\
\hline \multirow[t]{3}{*}{ January 1970} & All moles & 100 & 78.3 & 4.3 & 8.7 & 2.2 & 45.7 \\
\hline & Males & 100 & 78.6 & 3.6 & 10.7 & - & 46.4 \\
\hline & Females & 100 & 77.8 & 5.6 & 5.6 & 15.6 & 44.4 \\
\hline
\end{tabular}

\subsection{Stomach Content Weight and Diet in Males and Females}

There was no significant difference between months in the weight of stomach contents showing that seasonal changes in soil conditions did not affect the food consumption. The stomach content weight was approximately equal in the sexes in each month and on the average (Table 2). However the mean weight of the full stomach was significantly higher in males (Mean $\pm \mathrm{SE}=6.7 \pm 2.7$ g.) than in females ( $5.4 \pm$ $2.5 \mathrm{~g}$.). This is because the empty stomach which could constitute from $10-90 \%$ of the weight of the full stomach was significantly heavier $(P=0.05)$ in males $(0.98 \pm 0.17$ g. $)$ than in females $(0.86 \pm 0.20$ g.) The frequencies of occurrence of the main food items and the percentage weight of earthworms in the stomach contents were similar in males and females in all months (Table 1) indicating that the diet was basically similar in the sexes.

\subsection{Stomach Content Weight and Diet in Adults and Juveniles}

The weight of the stomach contents was also similar in adults and juveniles in both sexes (Table 2). The proportion of stomachs containing 
qualitative composition of the diet of moles.

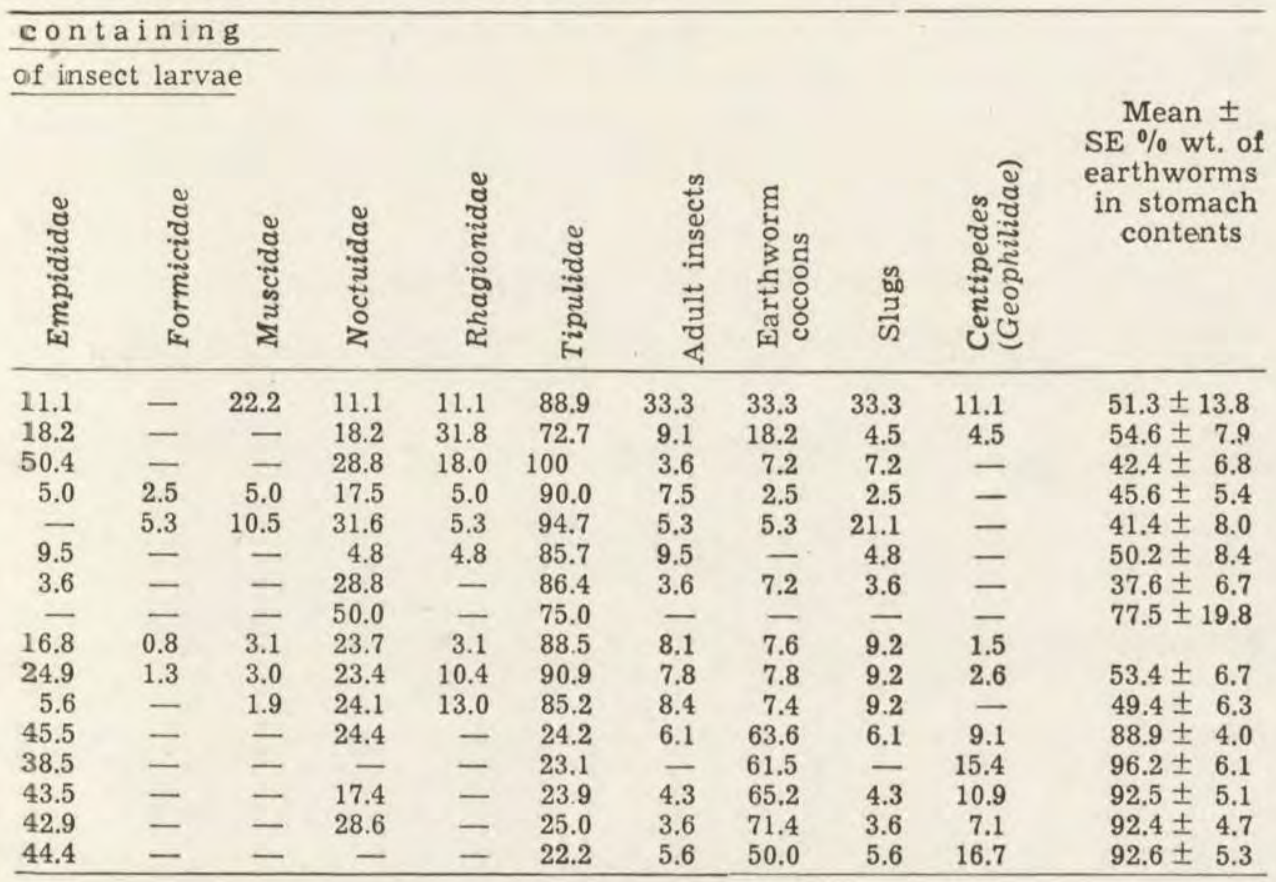

each category of invertebrates and the proportion by weight of earthworms in the diet were similar in adults and juveniles (Table 1).

\subsection{Local Variations in Stomach Content Weight and Diet}

The mean $( \pm \mathrm{SE})$ stomach content weight was $4.8 \pm 2.2 \mathrm{~g}$. in Leip field and $5.4 \pm 2.2 \mathrm{~g}$. in Bilston field indicating that there was no significant difference $(P=0.05)$ between the two localities. A few species of invertebrates were found in one locality but not in the other but the biomass of earthworms in the diet was similar in both localities (Table 1) indicating the basic similarities in the diet in these two localities.

\subsection{Food Preferences}

The six most common items of the mole's diet in the soil (earthworm cocoons, earthworms, insect larvae, Tipulidae, Dolichopodidae and Elateridae larvae) were also, except earthworm cocoons, the most commonly encountered components of the stomach contents (Table 3) indicating that suitable invertebrates which are distributed abundantly in the soil are the ones most frequently eaten by the mole. However, in spite 
of their abundance in the soil, earthworm cocoons were seldom eaten by moles suggesting that these were not a favourite item of the mole's diet, maybe because they are small and immobile and therefore not easily located. In fact earthworm cocoons were not eaten by juvenile

Table 2

Stomach content weight (Mean \pm S. E.) in moles.

\begin{tabular}{llc}
\hline Month & \multicolumn{1}{c}{ Sex and Age } & $\begin{array}{c}\text { Stomach Content } \\
\text { wt. (g.) }\end{array}$ \\
& All moles & $6.2 \pm 3.5$ \\
March 1969 & Males & $7.3 \pm 3.1$ \\
& Females & $1.9 \pm 0.3$ \\
& All moles & $5.4 \pm 3.6$ \\
April 1969 & Males & $5.9 \pm 3.6$ \\
& Females & $4.3 \pm 3.3$ \\
May 1969 & All moles & $5.7 \pm 1.3$ \\
& Males & $5.4 \pm 2.1$ \\
& Females & $6.2 \pm 1.9$ \\
& All moles & $5.2 \pm 2.4$ \\
June 1969 & Adult males & $5.7 \pm 1.7$ \\
& Juvenile males & $5.3 \pm 2.9$ \\
& All males & $5.5 \pm 2.4$ \\
& Adult females & $5.5 \pm 2.3$ \\
& Juvenile females & $4.5 \pm 2.2$ \\
& All females & $5.0 \pm 2.3$ \\
& All moles & $4.8 \pm 2.2$ \\
July 1969 & Adult males & $2.9 \pm 0.8$ \\
& Juvenile males & $5.6 \pm 2.2$ \\
& All males & $5.3 \pm 2.3$ \\
& Adult females & $2.9 \pm 0.8$ \\
& Juvenile females & $4.3 \pm 1.8$ \\
January 1970 & All females & $4.1 \pm 1.8$ \\
& All males & $4.3 \pm 3.2$ \\
August 1969 & Males & 8.2 \\
& Females & $4.7 \pm 2.5$ \\
August 1969 & Males & $5.8 \pm 2.8$ \\
& Females & $4.7 \pm 2.5$ \\
& All moles & $5.1 \pm 2.2$ \\
& Males & $5.5 \pm 2.5$ \\
& Females & $4.3 \pm 1.8$ \\
\hline
\end{tabular}

moles (Table 1). On the other hand Noctuid larvae were found in only two soil samples but in a high proportion of stomachs indicating that unless the method of sampling was unsuitable for this species, moles prefer this item of their diet, possibly because its large size makes it easily located by moles. 


\subsection{Food Storage}

Fortresses were not built by all mole but only by some of those living in deep soils. Where fortresses were not built, nests were placed under relatively large mole-hills. New fortresses were built between the end of December and early January.

Fortresses examined in March and October, 1968 and in March and May 1969 did not contain earthworm stores indicating that wild moles did not lay stores at these periods. All the fortresses $(N=5)$ examined

Table 3

Percentage occurrencies of invertebrates in stomach contents of moles and in soil samples in Boghall glen.

\begin{tabular}{lcc}
\hline \multicolumn{1}{c}{ Invertebrates } & $\begin{array}{c}\text { \% No. of stomach } \\
\text { contents containing }\end{array}$ & $\begin{array}{c}\text { \% } \\
\text { samples of soil }\end{array}$ \\
\hline Earthworms & 98.0 & 62.0 \\
All insect larvae & 100 & 59.5 \\
Bibionidae & 28.6 & 4.5 \\
Carabidae & 44.9 & 4.0 \\
Dolichopodidae & 42.9 & 17.0 \\
Elateridae & 55.1 & 14.0 \\
Empididae & 34.7 & 5.5 \\
Formicidae & 2.0 & 0.5 \\
Muscidae & 0 & 7.0 \\
Noctuidae & 26.5 & 1.0 \\
Rhagionidae & 24.5 & 2.5 \\
Tipulidae & 89.8 & 30.5 \\
Adult insects & 10.2 & 1.5 \\
Earthworm cocoons & 6.1 & 76.5 \\
All slugs & 8.2 & 4.0 \\
Arion fasciatus & 2.0 & 2.0 \\
Agrolimax reticulatus & 8.0 & 2.5 \\
Centipedes (Geophilidae) & 2.0 & 0 \\
\hline
\end{tabular}

in February 1969 contained earthworms with healed, decapited and mutilated bodies which indicated that the injuries were inflicted earlier on when the stores were laid, presumably after October, 1968 when last unsuccessful search was made.

The healed injuries showed that the pre-storage biting by moles will not normally kill the earthworms, the only two dead members of the stores being uninjured (Table 4). The presence of both injured and uninjured earthworms in the stores suggested that some were deliberately stored by the moles while some others wandered into the stores. Majority of the larger species (Lumbricus terrestris, Octolasium cyaneum) and to some extent the medium-sized species (Lumbricus rubellus, Allolobophora caliginosa) were injured while the smaller ones (Allolobophora 
chlorotica, Dendrobaena rubida and Eisenia rosea were uninjured (Table: 4).

The species composition of earthworms in fortress stores corresponded with that in the local soils (Table 4) which shows that moles gathered their stores in the immediate vicinities of their fortresses. However, the proportion of some species in the stores did not correspond with their relative abundance in the soil. Thus, the larger species $L$. terrestris and O. cyaneum, formed $6.8 \%$ and $6.1 \%$ of store populations but only $1.7 \%$ each of the local soil populations whereas a smaller species, L. rubellus, formed $32.8 \%$ of soil populations but only $2.2 \%$ of store populations which suggests that the mole tends to store the large species of earthworms.

Table 4

Physical conditions of earthworms stored in five mole fortressess and the proportional occurrence of earthworm species in mole stores and in the soil populations.

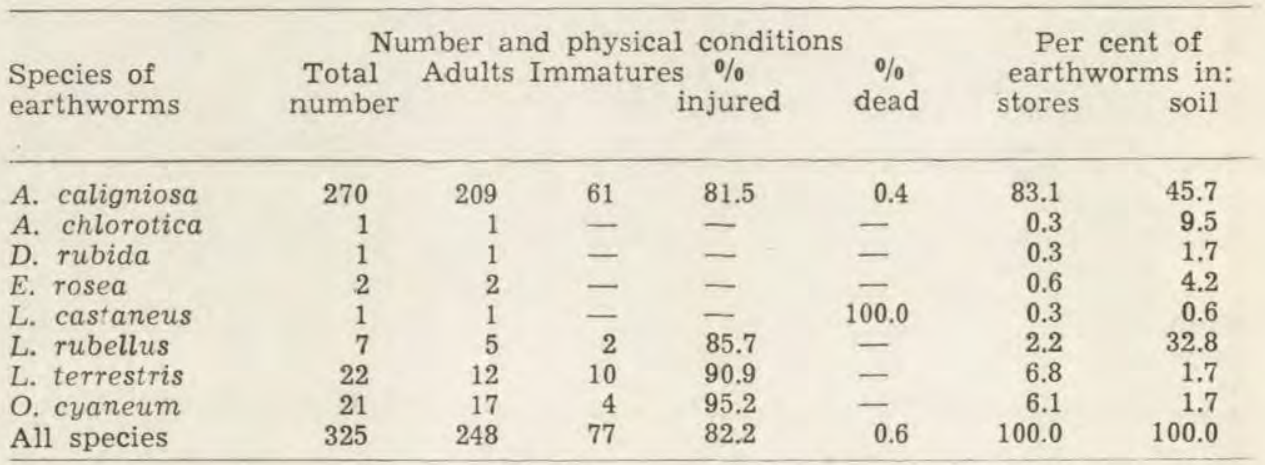

Moles kept in captivity between September and November 1968 mutilated and buried excess earthworms in the soils of their cages but they eventually consumed their stores unless they are continously provided with a fresh supply. The habit was first observed during investigations into how $100 \mathrm{~g}$. of earthworms fed to a captive mole at 9.00 a.m. disappeared totally by noon. Captive moles always preferred to eat first the smaller earthworms which were consumed usually from the head end and with their gut contents rejected. A fully satiated mole might still consume a small earthworms but not the whole or any substantial proportion of a large one except just to bite off the head region. The more frequent consumption of the small ones relative to the large ones may account for the preponderance of the large earthworms in the mole's stores. 


\section{DISCUSSION}

The present results show that the mole subsists mainly on earthworms and insect larvae which confirmed previous reports (White, 1914; A d a m s, 1920; Folit a rek, 1932; M a c D o u g a 1, 1942). The proportion by weight of earthworms in the diet was equal in the two localities investigated. Major differences may however be found in the diet of moles living in different localities. Thus, F u n mil a y o (1970) found that the percentage weight of earthworms in the diet of moles captured in December, 1967 to February, 1968 was significantly higher $(P=0.05)$ in those from a domestic garden (Mean $\pm \mathrm{SE}=98.0 \pm 11.0 \%$ ) and an old upland pasture $(84.0 \pm 5.4 \%)$ than in those from a two years old lowland pasture $(62.1 \pm 9.0 \%)$ which was previously an arable land and therefore probably relatively poor in earthworms.

The distribution of the major food items (earthworms and insect larvae) in the stomach contents of the mole parallels their distribution in the soil indicating that the mole has no major preferences for particular food items and thus confirming the results of $\mathrm{Kr} \mathrm{u}$ is htal (1934). The relative percentage weight of earthworms in the stomach contents was more than $50 \%$ in four months out of seven. The significantly higher $(P=0.05)$ biomass of earthworms in the diet in January, relative to the other months was probably due to more earthworms being obtained by moles at this period. Extensive digging occurs at this period because fortresses are being built while adult moles are enlarging their deep permanent tunnel systems and juvenile moles are just establishing permanent tunnel systems. The cold spell also drives earthworms deeper into the soil thereby making them more available to the mole both in its deep tunnels and also during the digging. This is also the period when earthworms are stored in fortressess and, as suggested by Skoczen (1961), the earthworms found in stores probably owe their origin to the excess obtained during digging and feeding.

The only group of insect larvae, Tipulidae, that could contribute significant biomass to the mole's diet in the present study area occurred in large sizes only between May to July, the period when insect larvae were relatively more important than earthworms in the mole's diet. From about May, when the soil was getting warmer, until July moles dug mainly surface runs and shallow tunnels which were presumably used to obtain insect larvae (Tipulidae) which were abundant in the superficial layers of soil, hence the relatively higher biomass of insect larvae in the mole's diet at this period.

The overall implications of the results on the diet and feeding habits of the mole is that the mole consumes all the suitable invertebrates it 
could obtain in the soil. The composition by weight of the diet at any particular time and place reflects mainly the relative biomass in the soil of the different categories of invertebrates that make up the diet and the relative ease with which the mole can obtain them.

Acknowledgement: This work is part of a $\mathrm{Ph}$. D. Thesis submitted to the University of Edinburgh. I am grateful to Dr. W. J. Guild who supervised the work.

\section{REFERENCES}

1. A dam S L. E., 1920: The life history of the commom mole. J. Ministr. Agric. 27: $659-665$.

2. Evans A. C., 1948: The identity of earthworms stored by moles. Proc. zool. Soc. Lond., 118: 356-359.

3. Folitarek S., 1932: The Distribution and Biology of the mole (Talpa europaea brauneri Satun) and mole catching in the Ukraine. Bull. Soc. Nat. Moscow, Biol., 41: 235-302.

4. F unmila yo O., 1970: Population studies on the distribution of moles (Talpa europaea L.) relative to food supply and general habitat. $\mathrm{Ph}$. D Thesis, University of Edinburgh: $1-254$.

5. Funmil a y o O., 1977: Daily food consumption of captive moles. Acta theriol., 22: $389-392$.

6. Gerard B. M., 1964: Synopses of the British fauna, No. 6 Lumbricidae (Annelida). Linnean Society, London, 1-58.

7. Godfrey G. K., 1955: A field study of the activities of the mole. Ecology, $36: 678-685$.

8. Godfrey G. \& Crowcroft, P., 1960: The life of the mole. Museum Press: $1-152$. London.

9. Guild W. J. McL., 1955: Soil zoology. Proceedings of the University of Nottingham second Easter School in Agricultural Science (D. K. McEkevan ed.) Butterworth, London; 83-96.

10. Kruishtal A. F., 1934: On the ecology and agricultural importance of the mole in the Forest-steppe west of the Dnipper and in the Polese of Ukraine, Zool. Ž., 13: 292-301.

11. Larkin P., 1948: The ecology of mole (T. europaea L.) populations. Unpublished D. Phil. thesis (Bodleian Library), Oxford: 1-134.

12. MacDougal R. S., 1942: The mole, its life history, habits and economis importance. Trans Highl. Agric. Soc. Scot., 54: 80-107.

13. Mella n by K., 1966: Mole activity in woodlands, fens and other habitats. J. Zool., Lond., 149: 35-41.

14. Mel1an by K., 1967: Food and activity in the mole (Talpa europaea). Nature, London, 215: 1128-1130.

15. Mellanby K., 1968: The ingenuity of the mole. Ctry. Life, 143: 954.

16. Mellanby K., 1973: The mole. William Colins Sons and Co. Ltd.: 1-159. Glasgow.

17. R a w F., 1959: Estimating earthworm populations by using formalin. Nature, London, 184: 1661-1662.

18. R aw F., 1966: The soil fauna as a source of food for moles. J. zool. Soc. London, 149: 50-54. 
19. Skoczeń S., 1961: On the food storage of the mole (Talpa europaea L.) Acta theriol., 5: $23-43$.

20. Skoczen .., 1966: Stomach contents of the mole (Talpa europaea L.) Acta theriol., $11: 28: 551-575$.

21. White P. Be, 1914: The food of the mole. J. Bd. Agric., 21: 401-407.

Accepted, March 5, 1979.

Oluwadare FUNMILAYO

KONSUMPCJA, WYBIORCZOSC I ZAPASY POKARMU KRETA

\section{Streszczenie}

Ważono zawartość żołądków kretów (Talpa europaea Linna e us, 1758), lapanych na pastwiskach południowo-wschodniej Szkocji, od marca do sierpnia $1969 \mathrm{r}$. i w styczniu $1970 \mathrm{r}$. (Tabela 2). Skład pokarmu ustalono na podstawie analizy treści żołądkowej, wydzielając z niej poszczególne gatunki dżdżownic i larw owadów i ważąc je.

Wybiórczość pokarmową określano porównując skład gatunkowy bezkręgowców w żołądkach i w próbkach glebowych (Tabela 3). Rozkopując kretowiska, stwierdzono robienie przez krety zapasów pokarmowych. Porównano skład gatunkowy dżdżownic w tych magazynach ze składem w otaczającej glebie (Tabela 4). Nie było istotnych różnic $(P=0.05)$ w ciężarze treści żołądkowej (Tabela 1) i w jakości pokarmu między zwierzętami łowionymi w poszczególnych miesiącach i miejscach, a także brak było różnic związanych z płcią i wiekiem kretów. Cieżar dżdżownic $\mathrm{w}$ diecie tego gatunku był jednakże istotnie wyższy $(P=0.05) \mathrm{w}$ styczniu $\mathrm{w}$ porównaniu z innymi miesiącami, natomiast larwy owadów stanowiły najważniejszy składnik pokarmu od maja do lipca. Zgodność składu gatunkowego w treści żołądkowej ze składem gatunkowym bezkręgowców w glebie, wskazuje na niewrelką wybiórczość pokarmową kretów. Zapasy robione są zarówno przez krety trzymane w niewoli jak i przez ,dzikie”. 